\title{
Characterization of Ornamental Malus Genotypes and the Study of Their Pollen Characteristics
}

\author{
Emilia MOISESCU*, Cosmin Alexandru MIHAI, Ana Cornelia BUTCARU, Vlad POPA, Florin STĂNICĂ \\ University of Agronomic Sciences and Veterinary Medicine of Bucharest, Romania \\ *corresponding author: emilia_moisescu@yahoo.com \\ BulletinUASVM Horticulture 77(1) / 2020 \\ Print ISSN 1843-5254, Electronic ISSN 1843-5394 \\ DOI:10.15835/buasvmcn-hort: 2019.0050
}

\begin{abstract}
Decorative apple species are used in different fields: breeding, landscape architecture, feeding of the birds during winter, etc. This paper presents the physicohemical characteristics of some ornamental apple genotypes grown and developed in the Northern area of Bucharest and the degree of pollen germination, according with area's climatic conditions. The results show that some fruits have a high total soluble content, up to $26.98 \%$ and dry matter up to $33.18 \%$, these ornamental apple genotypes can be recommended to be used in breeding to obtain new types of fruits for human consumption that have certain characteristics. The maximum percentage of pollen germination was $54.90 \%$ for the studied period, when during the efflorescence and blooming period massive rainfall occurred, but important for further research.
\end{abstract}

Keywords: breeding, dry matter, pollen germination, ornamental apple, total soluble solids

\section{Introduction}

Ornamental apple species are used in landscape architecture due to their characteristics, mainly size and longevity, decorating through: small size, canopy shape, colour and shape of leaves and flowers; shape, size, colour and abundance of fruits, their resistance on the tree until late winter. The biological characteristics of the decorative apple are important elements in landscaping, as: the growth rate - medium; longevity - small, under 100 years; the ability to erode - absent, generally or high; the invading character - the decorative apple is not an invasive species; toxicity - the ornamental apple has edible fruits, but some varieties can be quite astringent. Ornamental apple species are used in landscape arrangements in the form of: groups, consisting of 2-9 specimens, in street alignments or parks, isolated specimens, living fences, urban landscape orchards (Iliescu, 1998; Hsieh et al., 1995; Iliescu, 2003; Jing, 2014).

Beside the decorative effects, ornamental apple varieties contain bioactive and nutraceutical elements in fruits as well as in leaves and flowers, representing important sources of nutritional components used in human nutrition (Zhou et al., 2018), which makes them more and more studied (Ghena et al., 2004). Fang et al. (2018) carried out research on the chemical composition of the leaves, flowers and fruits of decorative apple varieties, of different colours. They concluded that the level of total phenols, flavonoids and anthocyanins (TPC, TFC and TAC) in flowers, leaves and fruits differ significantly both within the same variety and between varieties, as well as the fact that it is higher than 
in certain commercial apple varieties or other cultivated fruits, such as blackberries, currants and black currants. The study also showed that the analyzed varieties have a 10 times higher antioxidant capacity than some fruits known for their high values such as kiwifruit and olives. 12 phenolic compounds where identified, namely: 5 flavonoids (epicatechin, catechin, rutin, florizin, floretin) and 7 phenolic acids (gallic acid, salicylic acid, chlorogenic acid, vanillic acid, syringic acid, ferulic acid and ellagic acid). The flowers and the leaves are rich in flavonoids and the fruits in phenolic acids. Total content in ascorbic acid was found by Fang et al. (2017) greater in the wild and ornamental apples than in the cultivated ones. Ma et al. (2014) presented a comprehensive study comparing total soluble sugars and malic acid on 364 apple accessions, including ornamental apple.

Some varieties of ornamental apple, being good pollinators, are used in apple orchards, in different trees placement schemes (Lupescu, 1968; Stănică and Braniște, 2011; Babuc et al., 2013), others have importance in breeding (Cociu, 1999), some of them presenting sources of genes for resistance to diseases like apple scabs (Venturia inequalis), mildew (Podosphaera leucotrica), bacterial burn (Erwinia amylovora) (Sharma et al., 1982; Hoza, 2000; Grădinaru, 2002; Braniște and Uncheașu, 2011; Cornille et al., 2014; Lisandru et al., 2017; Choupannejad et al., 2018). Wang et al. (2019) presented the importance as rootstock genes in breeding. The knowledge of plant phylogeny is greatly facilitated by the study of pollen and spores (Pop, 1971; Tarnavschi et al., 1981; Serbănescu-Jitariu et al., 1994; Ramíreza and Davenport, 2013). Tolerance to salty soils were studied by Yang (2019).

\section{Material and methods}

The ornamental apple genotypes taken in this study are located in the arboretum park of the city of Chitila, located on the shore of Lake Chitila, in the North-West part of Bucharest (Southern Romania). The average altitude of the city of Chitila is $95 \mathrm{~m}$, the climate being characterized by droughty summers and frosty winters, average annual precipitation $500 \mathrm{~mm}$, being classified in a temperate - continental climate, with the average annual temperature of $10^{\circ} \mathrm{C}$, the absolute minimum temperature being
$-32{ }^{\circ} \mathrm{C}$ and absolute maximum temperature $41.1^{\circ} \mathrm{C}$.

The species/varieties studied are: Malus Perpetu 'Evereste', Malus $\times$ robusta 'Red Sentinel', Malus $\times$ scheideckeri 'Red Jade' (pendulum), Malus $\times$ zumi 'Golden Hornet', Malus Toringo 'Scarlett', Malus purpurea spp.

The productivity of the trees and physicohemical characteristics of the fruits (size, firmness, total soluble solids, dry matter) were analysed. For the fruits size a digital calliper was used. To measure the firmness of the pulp, the determination being carried out with the help of the penetrometer. Total soluble solids $\left({ }^{\circ} \mathrm{Bx}\right)$ were determined with the help of the portable digital refractometer. In the case of the Malus Toringo 'Scarlett' and Malus $\times$ scheindeckeri 'Red Jade' varieties, $10 \mathrm{~g}$ of hot water were mixed with $10 \mathrm{~g}$ of mesocarp and the soluble dry matter was determined from the resulting juice. In order to determine dry matter, the fruits were chopped (epicarp, mesocarp, endocarp) and the resulting mixture was analysed using thermobalance.

Many of the decorative apple varieties are commonly used in commercial apple orchards as they are good pollinators and with a longer flowering period. There were studied certain pollen characteristics of the analyzed species, such as: size and colour of anthers, grains of pollen and their degree of germination under certain conditions. Thus, on April 2, 2019 and April 9, 2019, there were harvested flower buds from all six species, removed their anthers and placed in Petri dishes with $10 \%$ sugary solution, using pure sucrose (99.8\%) (Fig. 1.).

Three hours after dissemination on Petri dishes each sample was analysed under the optical microscope and found, on both days, that all varieties, with the exception of the Malus Toringo 'Scarlett' variety, had begun the pollen germination process.

On the samples collected on April 9, 2019 it was checked the percentage of germination of pollen grains in 24 hours and 48 hours after contact with the sugary solution (Fig. 2). In order to determine the degree of germination, there were taken 15 pictures of each sample, from different microscopic fields, avoiding the areas with pollen clusters but also those with less than 10 grains, after which by counting all the germinated and non-germinated grains 


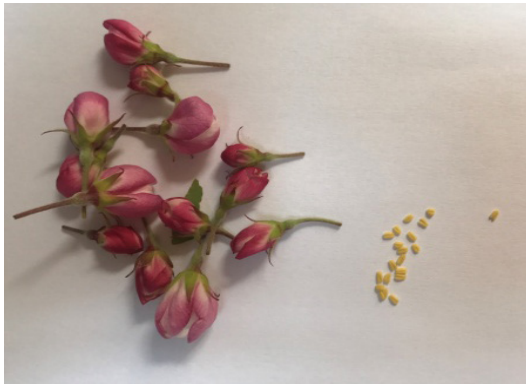

A

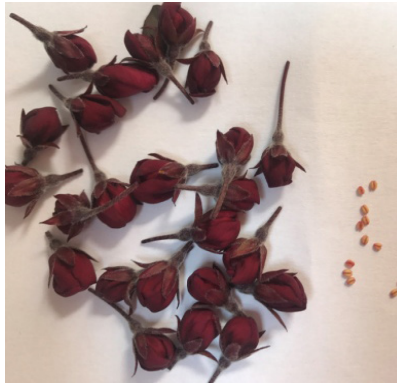

B

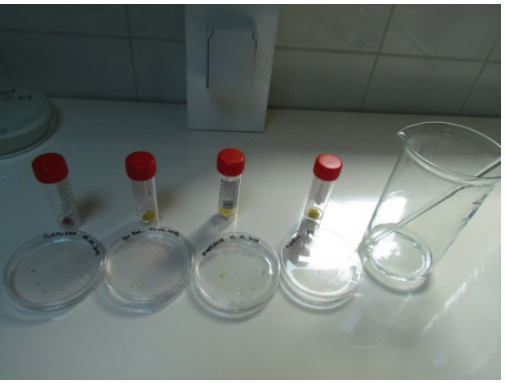

C

Figure 1. Flower buds and anthers of Malus 'Red Sentinel' (A), Malus Toringo 'Scarlett' (B) and pollen prepared for study (C)

(source: original photography)

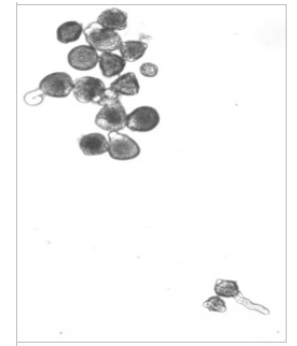

A

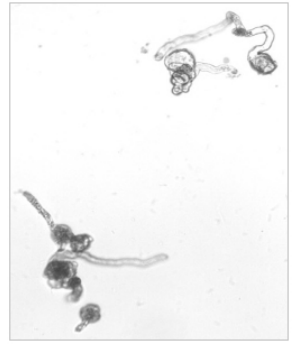

B

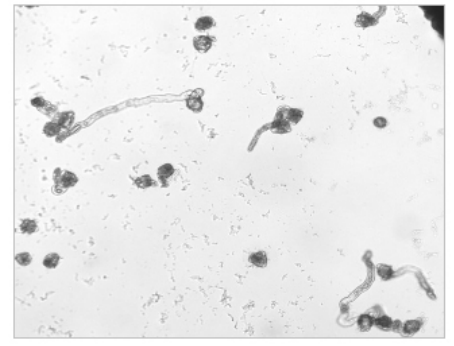

$\mathrm{C}$

Figure 2. Malus $\times$ zumi 'Golden Hornet' - pollen grains germinated after 3 hours (A), after 24 hours (B) and after 48 de hours (C)

Source: original photography

Table 1. Trees productivity (number of fruits/control branch)

\begin{tabular}{cccccc}
\hline Species-Variety & $\begin{array}{c}\text { Malus } \times \text { scheideckeri } \\
\text { 'Red Jade' }\end{array}$ & $\begin{array}{c}\text { Malus } \\
\text { 'Red Sentinel' }\end{array}$ & $\begin{array}{c}\text { Malus } \\
\text { Toringo 'Scarlett' 'Golden Hornet' }\end{array}$ & $\begin{array}{c}\text { Malus } \times \text { zumi } \\
\text { 'Gpp. }\end{array}$ \\
\hline 13 July 2018 & 96 & 127 & 196 & 32 & 73 \\
\hline 13 June 2019 & 121 & 52 & 167 & 113 & 61 \\
\hline
\end{tabular}

resulted the germination percentage of pollen grains.

Determinations of the physical characteristics of anthers and pollen were made using the following equipment:

- for the size and colour of the anthers was used a trinocular stereomicroscope on a $10 \times$ scale. Measurements were made for 15 anthers of each species.

- the size of the pollen grains was determined using the optical microscope on a $100 \times$ scale. Measurements were made for 15 grains of each species.

- the dimensions of the anthers and of the pollen grains were determined using the microscopes connected to the PC with the Leica LFC Core DFC
295 photo-video camera controlled by specific software.

- the analysis of the surface of the pollen grains was performed with the scanning electronic microscope.

The determinations of the chemical characteristics of the fruits and the physical characteristics of the fruits, anthers and pollen were made within the Research Center for the Study of Agri-Food Products Quality within the U.A.S.V.M. Bucharest.

\section{Results and discussions \\ Biometric and biochemical characterization of fruits}

Comparing the data presented in Table 1, the varieties Malus 'Red Sentinel' and Malus $\times$ 
Table 2. Physical determinations of the fruits of the analysed varieties

\begin{tabular}{cccccccc}
\hline Species-Variety & $\begin{array}{c}\text { Length } \\
(\mathrm{mm})\end{array}$ & $\begin{array}{c}\text { Diam.1 } \\
(\mathrm{mm})\end{array}$ & $\begin{array}{c}\text { Diam.2 } \\
(\mathrm{mm})\end{array}$ & Form & $\begin{array}{c}\text { Peduncle } \\
\text { length } \\
(\mathrm{mm})\end{array}$ & $\begin{array}{c}\text { Pulp } \\
\text { firmness } \\
\left(\mathrm{kgf} / \mathrm{cm}^{2}\right)\end{array}$ & $\begin{array}{c}\text { Weight } \\
(\mathrm{g})\end{array}$ \\
\hline Malus Perpetu 'Evereste' & 15.99 & 20.74 & 20.86 & spherical-flattened & 15.14 & 11.23 & 4.15 \\
\hline Malus purpurea spp. & 22.28 & 23.87 & 21.65 & spherical & 16.21 & 10.76 & 5.79 \\
\hline $\begin{array}{c}\text { Malus } \times \text { scheideckeri } \\
\text { 'Red Jade' }\end{array}$ & 14.80 & 14.31 & 14.32 & spherical & 40.12 & 9.78 & 1.75 \\
\hline Malus 'Red Sentinel' & 11.78 & 21.89 & 21.89 & spherical-flattened & 28.65 & 8.25 & 5.10 \\
\hline Malus Toringo 'Scarlett' & 12.98 & 16.00 & 15.72 & spherical-flattened & 35.43 & 9.92 & 1.62 \\
\hline $\begin{array}{c}\text { Malus } \times \text { zumi } \\
\text { 'Golden Hornet' }\end{array}$ & 19.00 & 19.37 & 21.10 & spherical & 20.02 & 8.20 & 4.05 \\
\hline
\end{tabular}

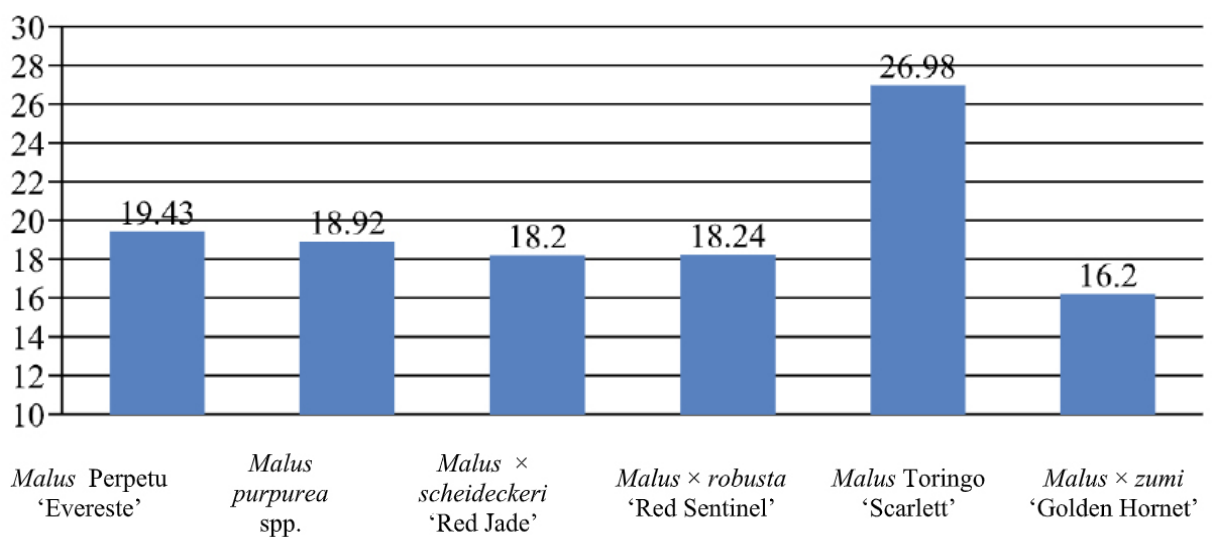

Figure 3. Content of apple fruits in total soluble sugars (\%)

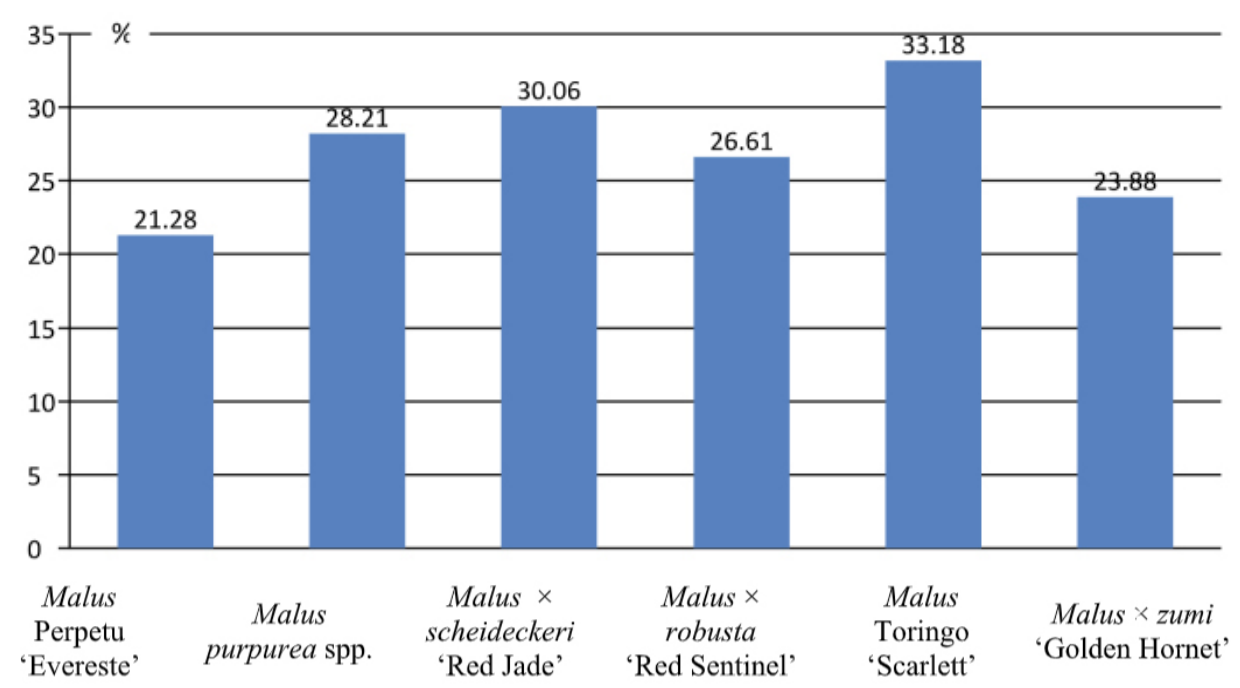

Figure 4. Content of dry matter in ornamental apple genotypes (\%)

zumi 'Golden Hornet' are in strong alternation of fructification, the differentiation of the fruit buds being very different in two years (2018 and 2019), which means that for their use as pollinator in a commercial orchard, fruiting pruning has to be applied every year to ensure a balance between the growth of the sprouts and the differentiation of the small buds in order to obtain as many pollenbearing flowers as possible. 


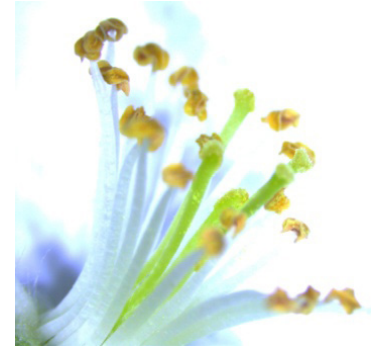

A

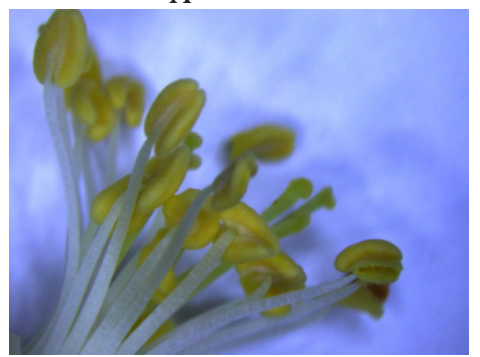

D

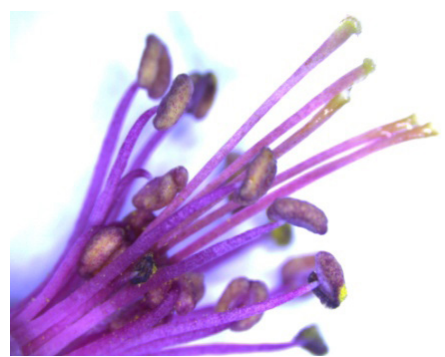

B

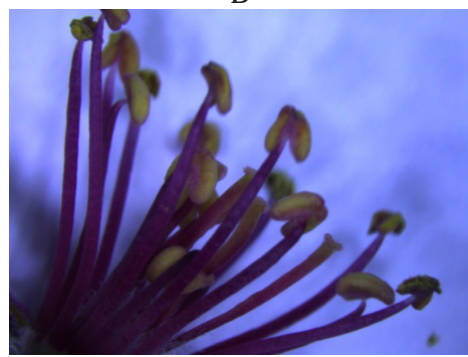

E

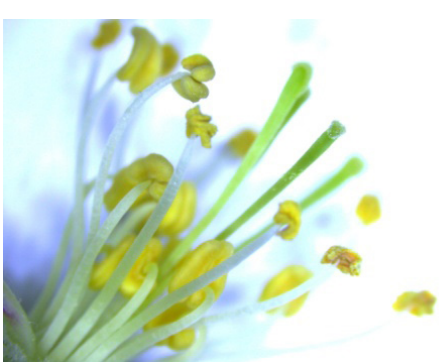

C

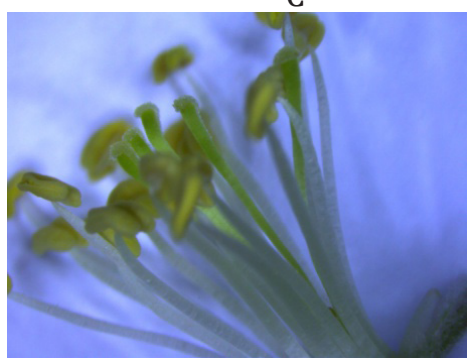

$\mathrm{F}$

Figure 5. Disposition of the anthers as opposed to the stigma in Malus Perpetu 'Evereste' (A), Malus purpurea spp. (B), Malus $\times$ scheideckeri 'Red Jade' (C), Malus 'Red Sentinel' (D), Malus Toringo 'Scarlett' (E) și Malus $\times$ zumi 'Golden Hornet' (F)

(source: original photography)

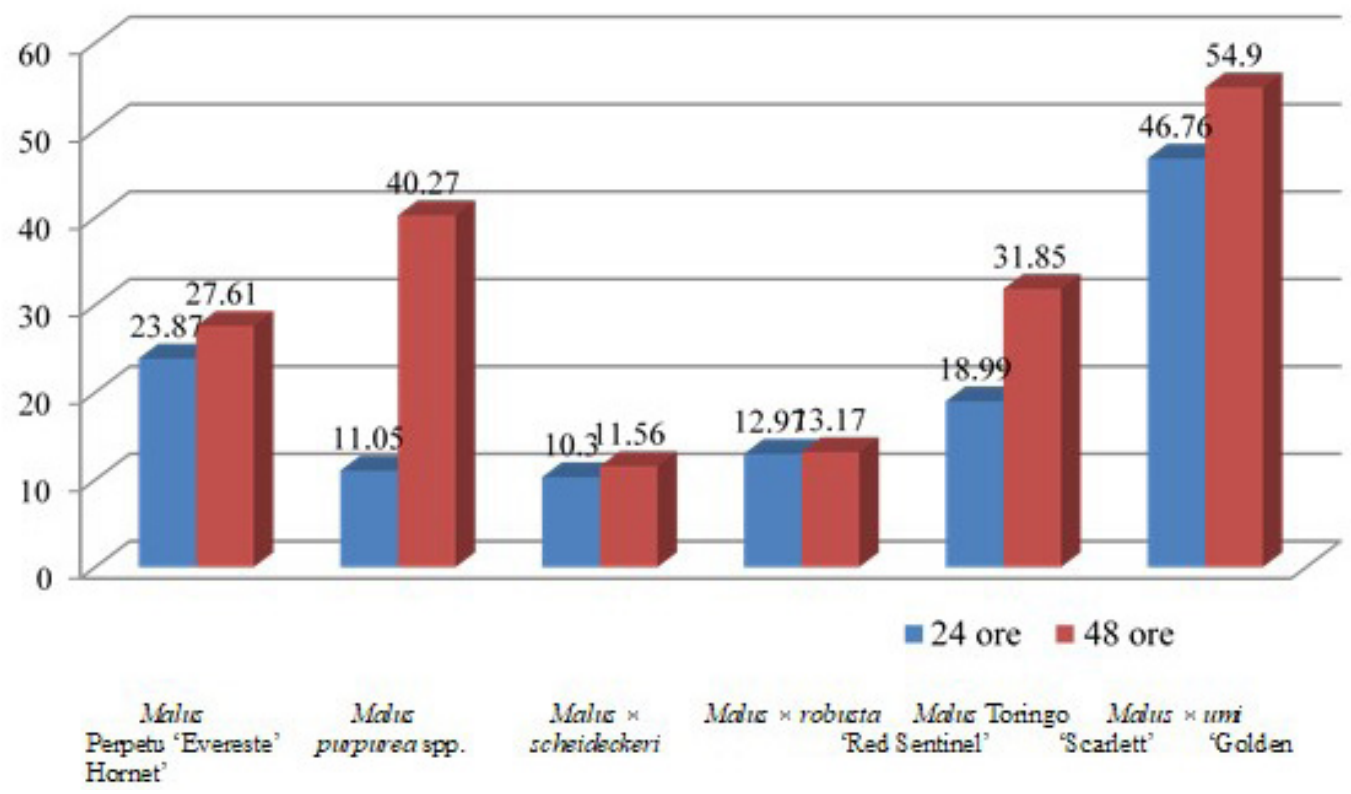

Figure 6. The germination percentage of pollen grains

The largest fruits, both in weight and size, are found in Malus purpurea spp. and the smallest in Malus $\times$ scheideckeri 'Red Jade' and Malus Toringo 'Scarlett' (Tab. 2). In terms of firmness the highest value was determined at Malus Perpetu 'Evereste' and the lowest at Malus $\times$ zumi 'Golden Hornet'.
The highest amount of sugars was found in Malus Toringo 'Scarlett' (26.98\%) and the lowest in Malus × zumi 'Golden Hornet' (16.2\%) (Fig. 3).

The highest content of dry matter was found in the fruits of Malus Toringo 'Scarlett' (33.18\%) and the smallest in those of Malus Perpetu 'Evereste' (21.27\%) (Fig. 4). 
Table 3. Size and colour of anthers

\begin{tabular}{ccccccc}
\hline Species/variety & $\begin{array}{c}\text { Malus } \\
\text { Perpetu } \\
\text { 'Evereste' }\end{array}$ & $\begin{array}{c}\text { Malus } \\
\text { purpurea } \\
\text { spp. }\end{array}$ & $\begin{array}{c}\text { Malus } \times \\
\text { Scheindeckeri } \\
\text { Jade' }\end{array}$ & $\begin{array}{c}\text { Malus } \\
\text { 'Red Sentinel' }\end{array}$ & $\begin{array}{c}\text { Malus } \\
\text { Toringo } \\
\text { 'Scarlett' }\end{array}$ & $\begin{array}{c}\text { Malus } \times \text { zumi } \\
\text { 'Golden Hornet' }\end{array}$ \\
\hline Length mm & 1.773 & 1.288 & 1.718 & 1.913 & 1.232 & 1.745 \\
\hline Width mm & 1.114 & 1.07 & 1.140 & 0.953 & 0.944 & 1.136 \\
\hline Shape index & 1.588 & 1.203 & 1.507 & 2.007 & 1.305 & 1.536 \\
\hline Colour & yellow & violet & yellow & yellow & violet & yellow \\
\hline
\end{tabular}

Table 4. Size of pollen grains

\begin{tabular}{ccccccc}
\hline Species/variety & $\begin{array}{c}\text { Malus } \\
\text { Perpetu } \\
\text { 'Evereste' }\end{array}$ & $\begin{array}{c}\text { Malus } \\
\text { purpurea } \\
\text { spp. }\end{array}$ & $\begin{array}{c}\text { Malus } \times \\
\text { Scheindeckeri } \\
\text { 'Red Jade' }\end{array}$ & $\begin{array}{c}\text { Malus } \\
\text { 'Red } \\
\text { Sentinel' }\end{array}$ & $\begin{array}{c}\text { Malus } \\
\text { Toringo } \\
\text { 'Scarlett' }\end{array}$ & $\begin{array}{c}\text { Malus } \times \text { zumi } \\
\text { 'Golden Hornet' }\end{array}$ \\
\hline Length nm & 3.020 & 3.075 & 2.955 & 3.050 & 3.010 & 3.235 \\
\hline Width nm & 2.735 & 2.770 & 2.618 & 2.839 & 2.800 & 2.959 \\
\hline Shape index & 1.104 & 1.110 & 1.128 & 1.074 & 1.075 & 1.093 \\
\hline
\end{tabular}

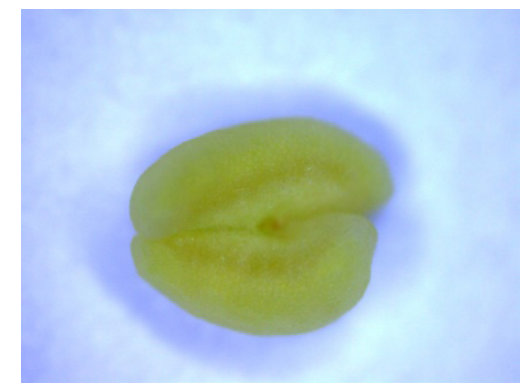

A

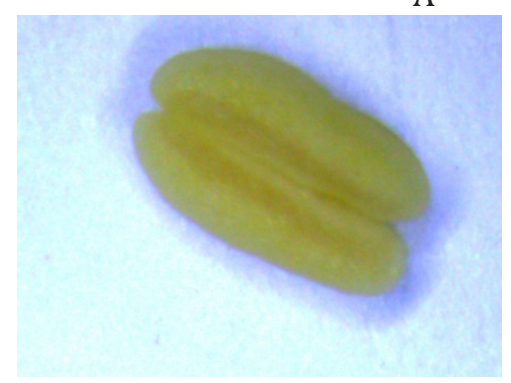

D

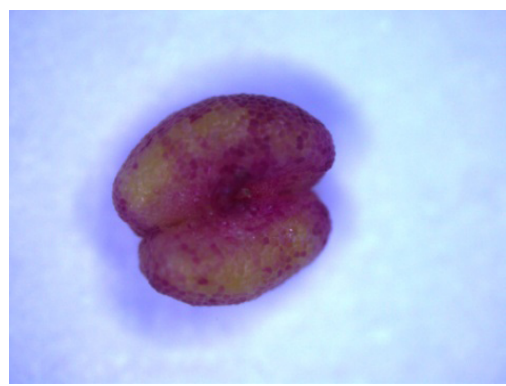

B

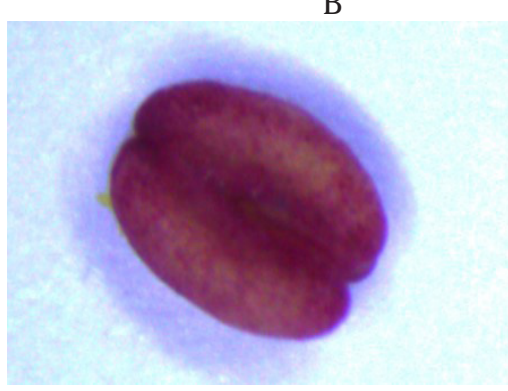

$\mathrm{E}$

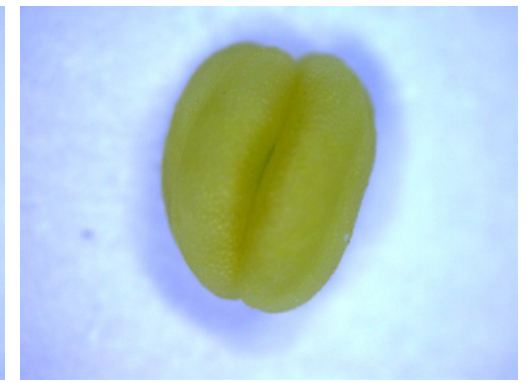

C

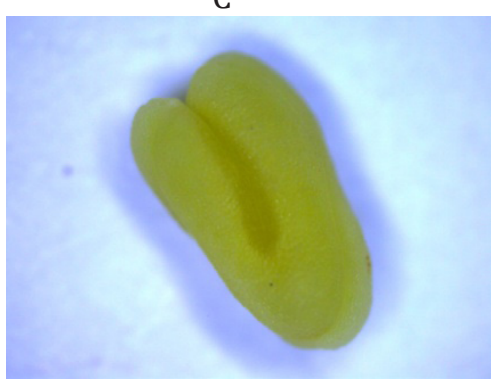

$\mathrm{F}$

Figure 7. Anthers from Malus Perpetu 'Evereste' (A), Malus purpurea spp. (B), Malus $\times$ scheideckeri 'Red Jade' (C), Malus 'Red Sentinel' (D), Malus Toringo 'Scarlett' (E) and Malus $\times$ zumi 'Golden Hornet' (F)

(source: original photography)

Both total soluble solids and the dry matter of the analysed fruits far exceed those of the fruits from the cultivated assortment in orchards for human consumption (Bărăscu et al., 2016; Bezdadea-Cătuneanu et al., 2017).

\section{Pollen characteristics of the analysed species}

Regarding pollination, being influenced by the arrangement of the anthers as opposed to the stigma/brand (Fig. 5), especially in the case of the self-fertile species, it is observed that the species
Malus Perpetu 'Evereste', Malus $\times$ scheindeckeri 'Red Jade', Malus 'Red Sentinel', Malus Toringo 'Scarlett', Malus $\times$ zumi 'Golden Hornet' have the anthers at the level of the stigmas ensuring better self-pollination, while the stigmas of flowers from Malus purpurea spp. are much above the anthers making the process of self-pollination much more difficult, situation in which the flowers need foreigner pollen.

It is also noted that the stamens of the species Malus purpurea spp. and Malus Toringo 'Scarlett' 


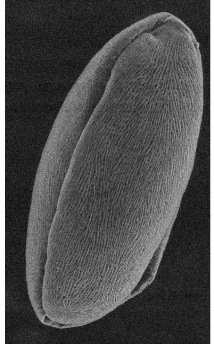

A

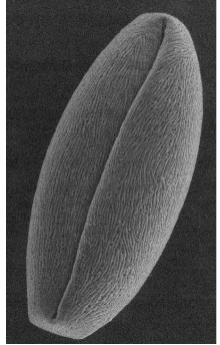

B

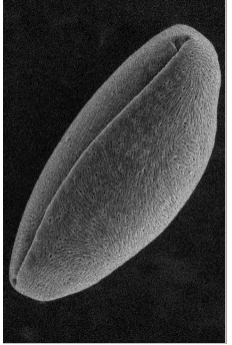

C

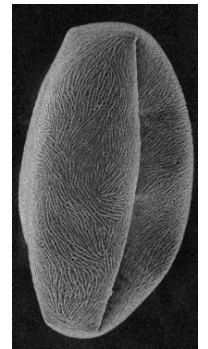

D

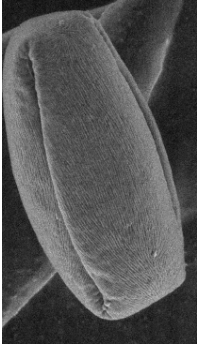

E

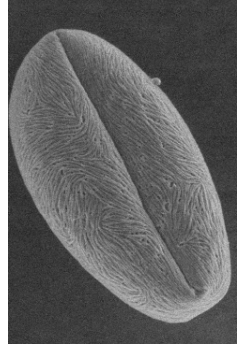

$\mathrm{F}$

Figure 8. Pollen grains from Malus Perpetu 'Evereste' (A), Malus x zumi 'Golden Hornet' (B), Malus x scheideckeri 'Red Jade' (C), Malus purpurea spp.(D), Malus 'Red Sentinel' (E) and Malus Toringo 'Scarlett' (F)

(source: original photography)

are purple, both species having fruits with red pulp.

The highest percentage of germination was registered at the pollen grains of the Malus $\times$ zumi 'Golden Hornet' variety, and the smallest in the Malus $\times$ scheideckeri 'Red Jade' variety (Fig. 6). The results were influenced by the climatic factors, during the entire flowering period being abundant rainfall with a high atmospheric humidity and lower temperature.

From the determination of the calculated form index in Table 3, it is observed that all species have anthers with elongated shape (Fig. 7).

From the shape index calculated in Table 4, it is observed that all species have slightly elongated pollen grains. The length varies between 2.955 and $3.235 \mathrm{~nm}$ and the grains width between 2.618 and $2.959 \mathrm{~nm}$, slightly different from Ramirez and Davenport, 2013 that mention an average length of $4.0 \mathrm{~nm}$ and average width of $2.0 \mathrm{~nm}$.

In the images of the pollen grains of the species/varieties studied, it can be observed that, although the architecture of all exines has a striated pattern (similar with Ramirez and Davenport, 2013), they have many differences, being specific to each species/variety (Fig. 8).

\section{Conclusions}

The analysed fruits have a high content of total soluble solids, a high amount of dry matter, being interesting in breeding but also for obtaining different high value nutraceutical products.

The percentage of germination of pollen grains was not high, the result being due to the atmospheric conditions, occurrence of massive rainfalls during the efflorescence and blooming period. However, at the Malus Toringo 'Scarlett' variety, the germination process of the pollen began very quickly, only three hours after contact with the sugary solution.

\section{References}

1. Babuc V, Peșteanu A, Gudumac E, Cumpanici A (2013). Producerea merelor, Manual tehnologic. Chișinău Publishing House.

2. Bărăscu R, Hoza D, Bezdadea-Cătuneanu I, Năftănăilă M, Albulescu A (2016). Preliminary research regarding the grafting interstock and soil maintanance influence on fruit quality for Pinova variety. Agriculture and Agricultural Science Procedia 10: 167-171.

3. Bezdadea-Cătuneanu I, Bădulescu L, Dobrin A, Stan A, Hoza D (2017). Preliminary data on the behavior of apple varieties stored in controlled atmosphere (CA) rooms. Journal of Horticulture, Forestry and Biotechnology (JHFB), 21(3): 21-25.

4. Braniște N, Uncheașu G (2011). Determinator de mere. Ceres Publishing House, Bucharest.

5. Choupannejad R, Sharifnabi B, Bahar M, Talebi M (2018). Searching for resistance genes to Venturia inaequalis in wild and domestic apples in Iran. Scientia Horticulturae 232: 107-111.

6. Cociu V (1999). Progrese în ameliorarea plantelor horticole din România, Pomicultură. Ceres Publishing House, Bucharest.

7. Cornille A, Giraud T, Smulders MJM, Rolda'n-Ruiz I, Gladieux P (2014). The domestication and evolutionary ecology of apples. Trends in Genetics, 30(2): 57-65.

8. Fang T, Zhen Q, Liao L, Owiti A, Zhao L, Korban SS, Han Y (2017). Variation of ascorbic acid concentration in fruits of cultivated and wild apples. Food Chemistry, 225: 132137.

9. Fang L, Meng W, Min W (2018). Phenolic compounds and antioxidant activity of flowers, leaves and fruits of five decorative apple cultivars. Scientia Horticulturae, 235: 460-467.

10. Ghena N, Braniște N, Stănică F (2004). Pomicultură generală. Matrix Rom Publishing House, Bucharest. 
11. Grădinaru G (2002). Pomicultură specială. Ion Ionescu de la Brad Publishing House, Iași.

12. Hoza D (2000). Pomologie. Prahova Publishing House, Prahova.

13. Hsieh L, Moos M, Lin Y (1995). Characterization of apple 18 and $31 \mathrm{kd}$ allergens by microsequencing and evaluation of their content during storage and ripening. Journal Allergy Clin Immunol, 96(6): 960-970.

14. Iliescu AF (1998). Arboricultură ornamental. Ceres Publishing House, Bucharest.

15. Iliescu AF (2003). Arhitectură peisageră. Ceres Publishing House, Bucharest.

16. Lisandru TT, Füstös A, Dumitraș A, Mitre V (2017). Flower Development of Ornamental Crabapple According to BBCH Scale, Bulletin UASVM Horticulture 74(2): 147-148.

17. Lupescu F (1968). Cultura mărului. Agro-Silvică Publishing House, Bucharest.

18. Jing Z, Rong W, Cui-Xiang H, Zhi-quan M, Ling G, Xiang S (2014). Taxonomic analysis of volatiles emitted by ornamental crabapple flowers. Acta Ecologica Sinica 34: 213-218.

19. Ma B, Chen J, Zheng H, Fang T, Ogutu C, Li S, Han Y, Wu B (2015). Comparative assessment of sugar and malic acid composition in cultivated and wild apples. Food Chemistry 172: 86-91.
20. Pop E (1971). Progrese în palinologia românească. Academiei Republicii Socialiste România Publishing House, Bucharest.

21. Ramíreza F, Davenport TL (2013). Apple pollination: A review. Scientia Horticulturae 162: 188-203.

22. Sharma DP, Sharma YD, Rama HS (1982). Stomatal and tree growth characteristics of some crab apples. Scientia Horticulture, 17: 327--331.

23. Stănică F, Braniște N (2011), Ghid pentru pomicultori. Ceres Publishing House, Bucharest.

24. Șerbănescu-Jitariu G, Mitroiu-Rădulescu N, Rădulescu D (1994). Monografia polenului florei din România, IV, Academia Româna Publishing House, Bucharest.

25. Tarnavschi I, Șerbănescu-Jitariu G, Mitroiu-Rădulescu N, Rădulescu D (1981). Monografia polenului florei din România, I, Academia Republicii Socialiste România, Publishing House, Bucharest.

26. Yang HB, Yua YC, Wangb Y, Xub XF, Han ZH (2019). Distribution and re-transportation of sodium in three Malus species with different salt tolerance. Plant Physiology and Biochemistry 136: 162-168.

27. Wang Y, Li W, Xu X, Qiu C, Wu T, Wei Q, Ma F, Han Z (2019). Progress of Apple Rootstock Breeding and Its Use. Horticultural Plant Journal, 5(5): 183-191.

28. Zhou K, Hu L, Liu B, Li Y, Gong X, Ma F (2018). Identification of apple fruits rich in health-promoting dihydrochalcones by comparative assessment of cultivated and wild accessions. Scientia Horticulturae 233: 38-46. 